\title{
Technologies for waste heat recovery in offshore applications
}

\author{
Pierobon, Leonardo; Nguyen, Tuong-Van
}

Publication date:

2012

Document Version

Publisher's PDF, also known as Version of record

Link back to DTU Orbit

Citation $(A P A)$ :

Pierobon, L., \& Nguyen, T-V. (2012). Technologies for waste heat recovery in offshore applications. Poster session presented at Energieffektivisering for fremtiden, Kgs.Lyngby, Denmark.

\section{General rights}

Copyright and moral rights for the publications made accessible in the public portal are retained by the authors and/or other copyright owners and it is a condition of accessing publications that users recognise and abide by the legal requirements associated with these rights.

- Users may download and print one copy of any publication from the public portal for the purpose of private study or research.

- You may not further distribute the material or use it for any profit-making activity or commercial gain

- You may freely distribute the URL identifying the publication in the public portal

If you believe that this document breaches copyright please contact us providing details, and we will remove access to the work immediately and investigate your claim. 


\section{Technologies for waste heat recovery in offshore applications}

\section{Leonardo Pierobon ${ }^{1,}$, , Tuong-Van Nguyen ${ }^{1}$}

\footnotetext{
1 Technical University of Denmark, Department of Mechanical Engineering, Nils Koppels Allé, Building 403, 2800 Kgs. Lyngby, Denmark

* Corresponding author, Tel.: +45 4525 4129, Fax: +45 4588 4325, Email: Ipier@mek.dtu.dk
}

1 Motivation and background

With increasing incentives for reducing $\mathrm{CO}_{2}$ emissions, energy optimization on offshore platforms becomes a focus area. The waste heat recovery from the SGT-500 SIEMENS gas turbine utilized on the Draugen platform (Kristiansund) is investigated. Three possible technologies are considered: the air bottoming cycle (ABC), the organic Rankine cycle (ORC) and the steam Rankine cycle (SRC). Thermal efficiency, compactness, weight and investment cost are the major constraints.

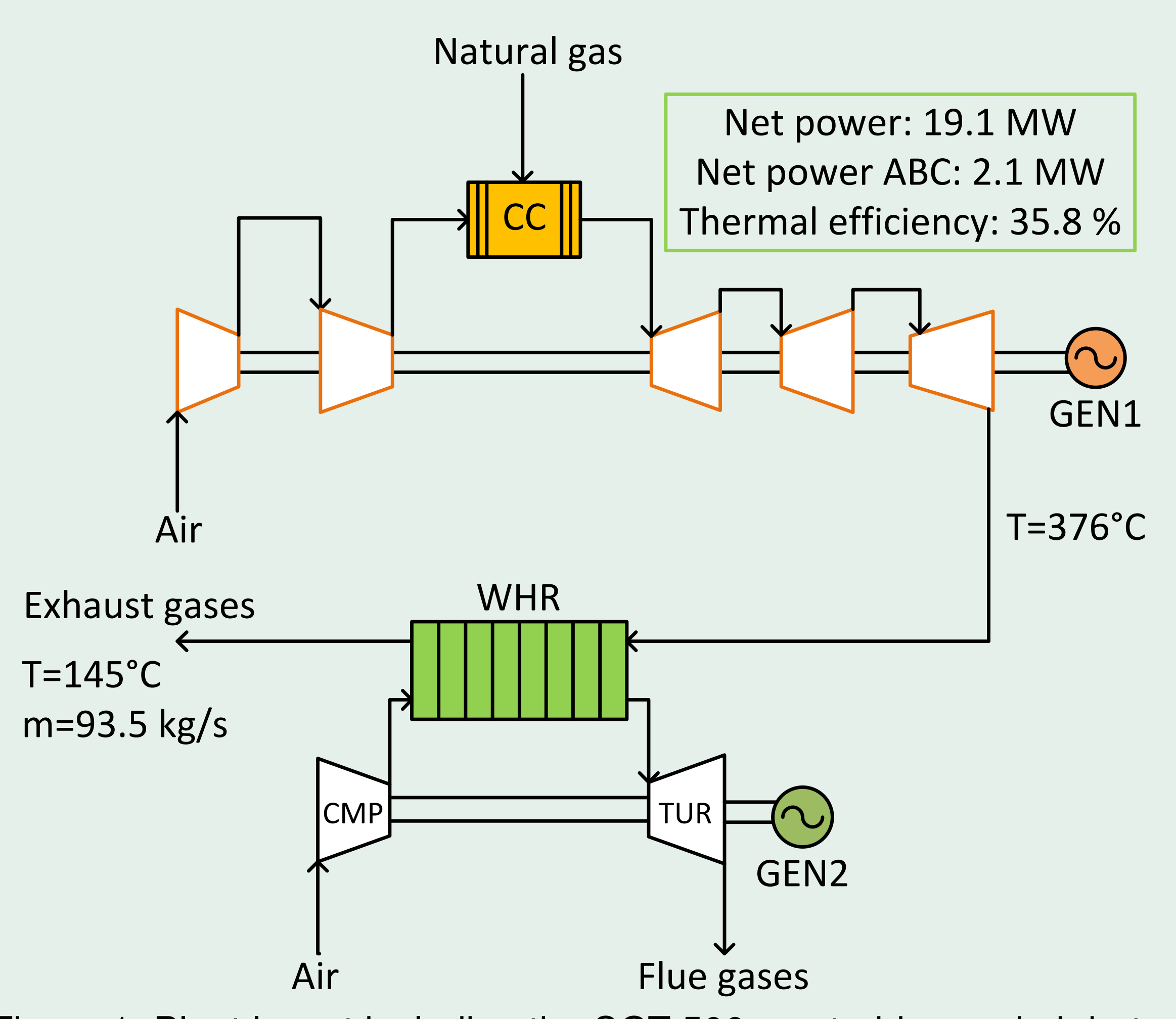

Figure 1: Plant layout including the SGT-500 gas turbine and air bottoming cycle

\section{Air bottoming cycle}

Pros:

- Simple layout (open cycle)

- No condenser is needed

- No intermediate loop

- Low hazard and environmental-friendly fluid

Cons:

- Low thermal efficiency

- Wide WHRU exchange area

- High turbine outlet temperature

\section{Organic Rankine cycle Pros:}

- High thermal efficiency (up to $44.3 \%$ )

- Compactness

- No moisture at turbine outlet ("dry" fluid)

- Flexibility in the working fluid selection

Cons:

- Intermediate loop

- High fire hazard

- New technology

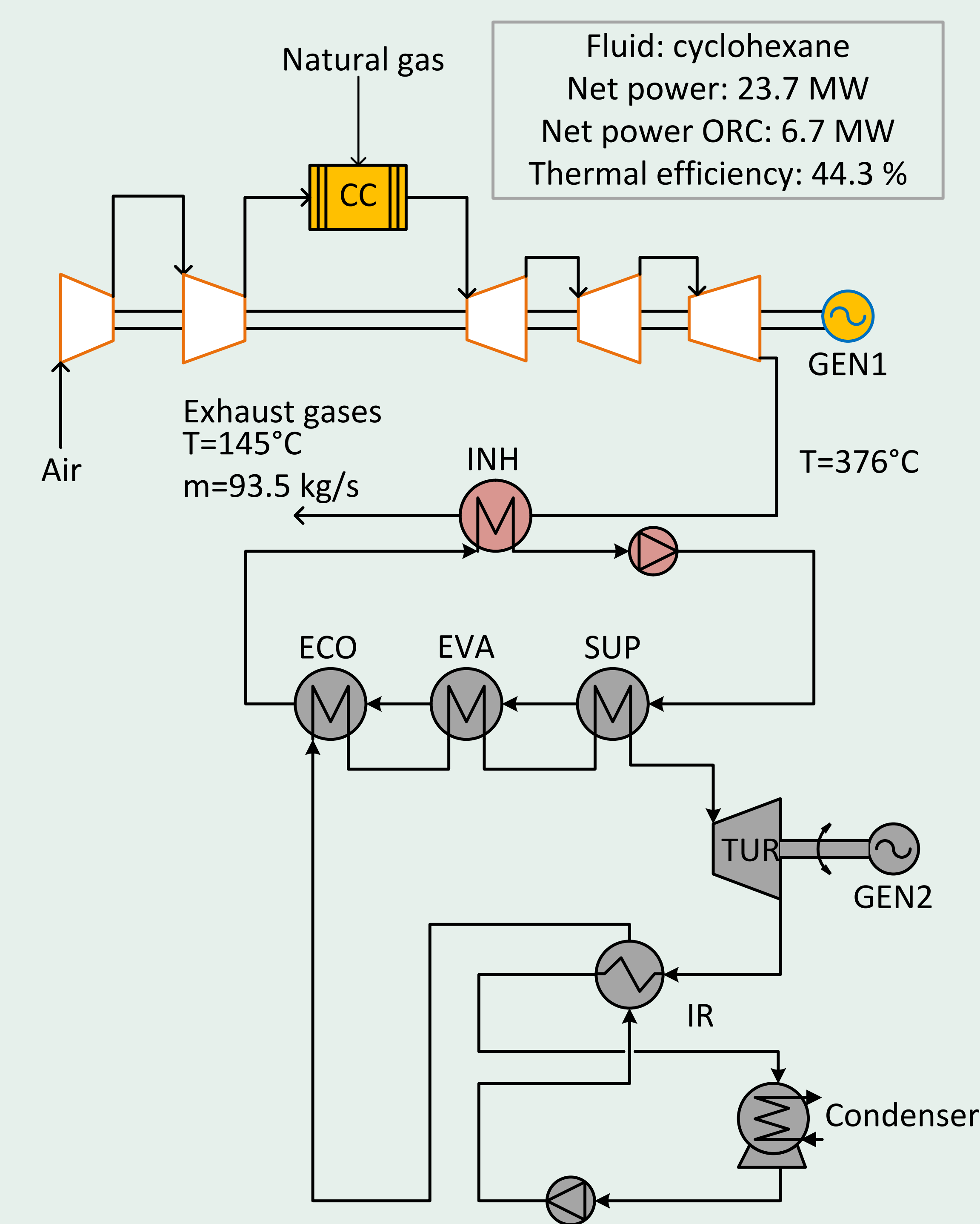

Figure 2: Plant layout including the SGT-500 gas turbine and organic Rankine cycle

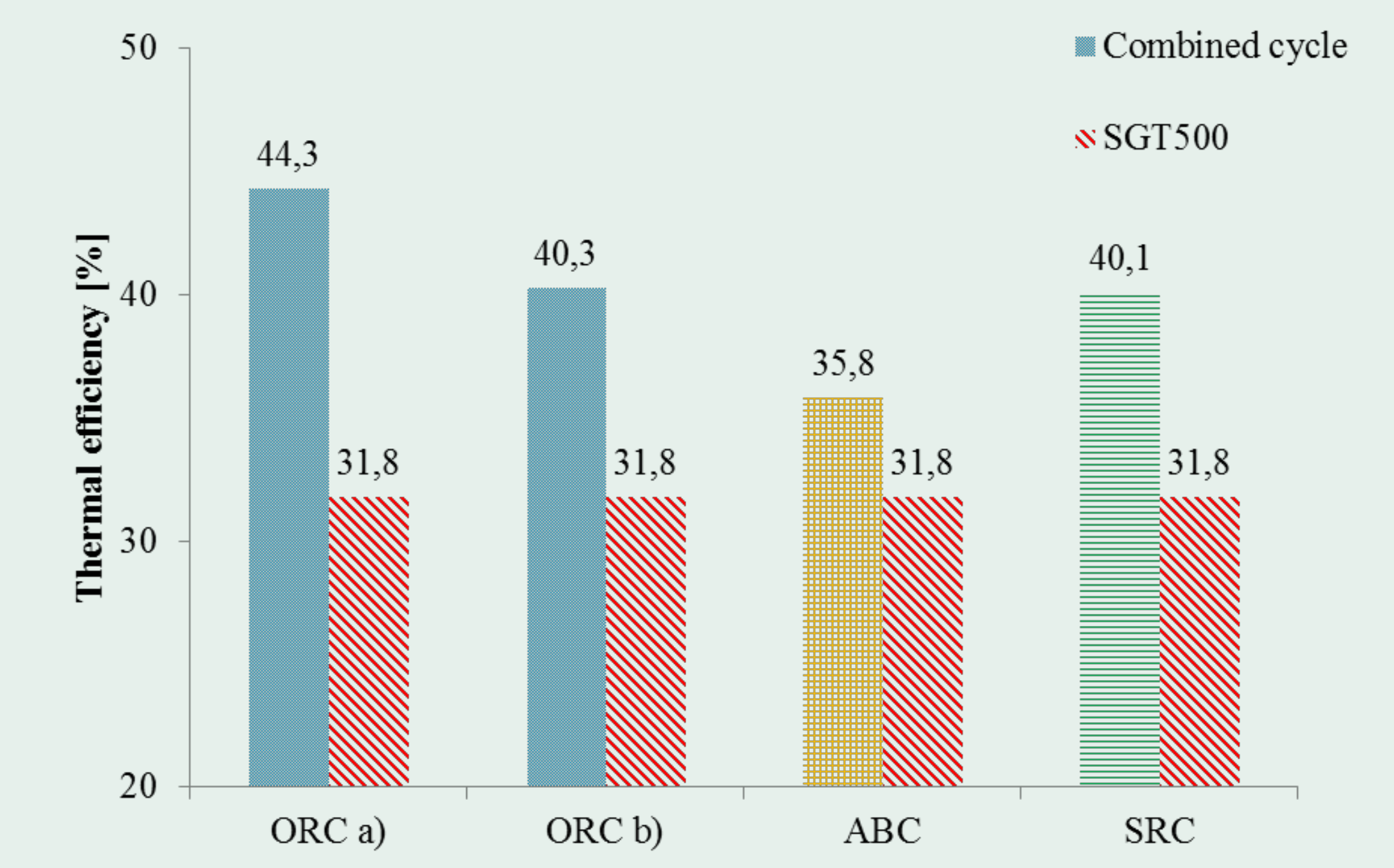

Figure 3: Comparison between the different waste heat recovery technologies
Steam Rankine cycle

Pros:

- Low maximum (10 bar) and high minimum pressures (0.1 bar)

- No intermediate loop

- Established technology

- Low hazard and environmental-friendly fluid Cons:

- Low thermal efficiency

- Moisture at steam turbine outlet (5\%)

- Need for make-up water

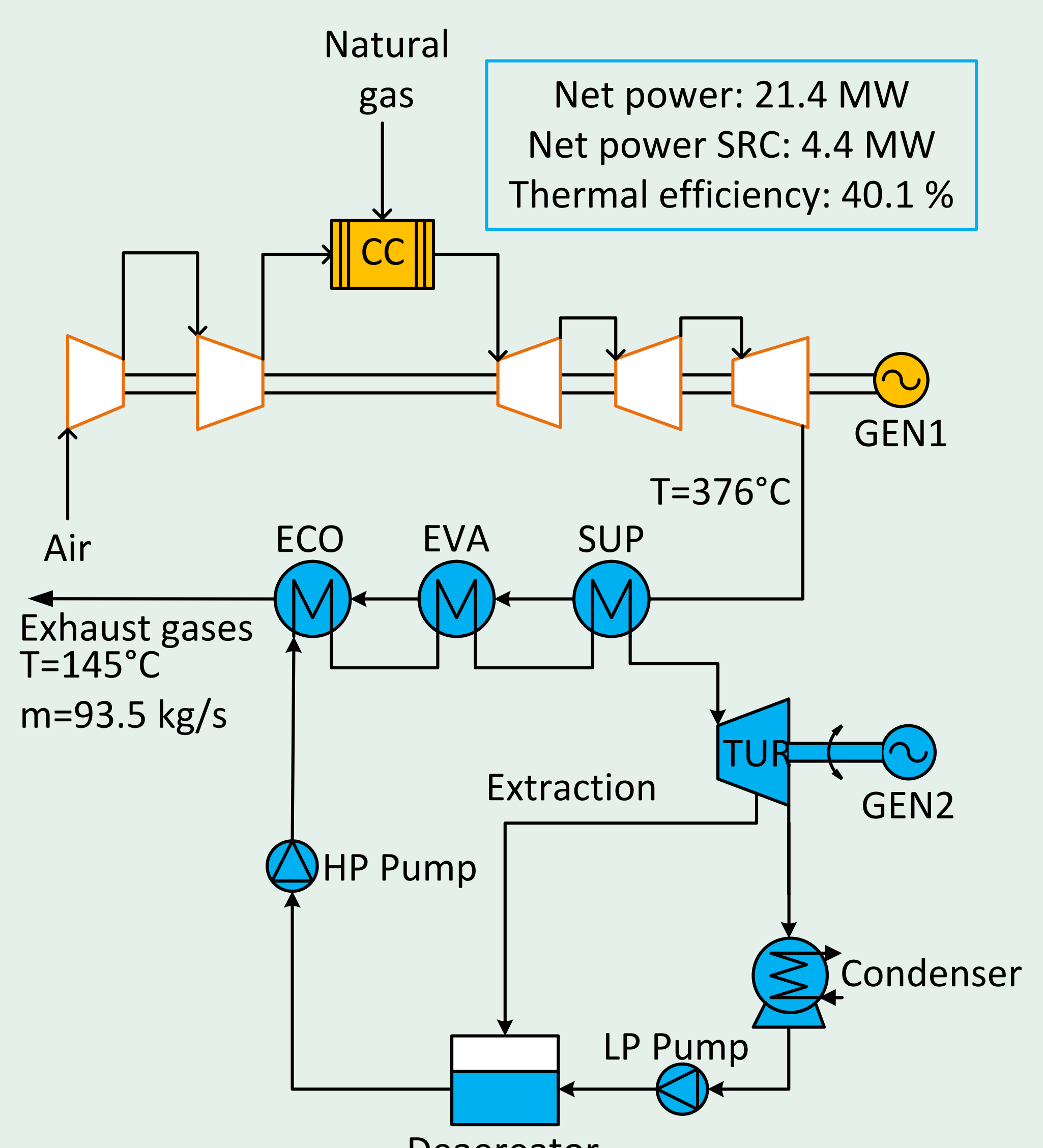

Figure 4: Plant layout including the SGT-500 gas turbine and steam Rankine cycle

\section{Results and discussion}

The combination of the SGT-500 and ORC presents the highest system performance $(44.3 \%)$ with cyclohexane (case a). When a low fire hazard is required carbon dioxide is the preferable media (case b). The ABC exhibits the lowest overall efficiency $(35.8 \%)$ due to the high outlet $A B C$ turbine temperature $\left(220^{\circ} \mathrm{C}\right)$. If a SRC is utilized problems related to moisture content after the expansion are encountered combined cycle efficiency is $40.2 \%$.

\section{Acknowledgements}

Funding from the Norwegian Research Council through Petromaks led by Teknova with project $\mathrm{n}^{\circ} 203404 / \mathrm{E} 30$ is acknowledged. 